UNIVERSITE DE BREST - BRETAGNE OCCIDENTALE

Faculté de Médecine \& des Sciences de la Santé

$* * * * *$

Année : 2015/2016

$\mathbf{N}^{\circ}$

THESE DE

DOCTORAT en MEDECINE

DIPLOME D'ETAT

Par

M. Idris DIALLO

Né le : 23 Août 1987 à : SARREBOURG

Présentée et soutenue publiquement le : 03 juin 2016

\title{
IS DUAL-ENERGY COMPUTED TOMOGRAPHY HELPFUL TO DETERMINATE THE FERROMAGNETIC PROPERTY OF BULLETS?
}

Président: $\quad$ M. le Professeur Douraied BEN SALEM

Membres du jury: M. le Professeur Luc BRESSOLLETTE

M. le Professeur Jean ROUSSET

Mme. le Docteur Claire SACCARDY

M. le Docteur Mathieu AUFFRET 
UBO

UNIVERSITE DE BRETAGNE OCCIDENTALE

FACULTE DE MEDECINE ET

DES SCIENCES DE LA SANTE DE BREST

DOYENS HONORAIRES

Professeur H. FLOCH

Professeur G. LE MENN ( $t)$

Professeur B. SENECAIL

Professeur J. M. BOLES

Professeur Y. BIZAIS ( $t)$

Professeur M. DE BRAEKELEER

DOYEN

Professeur C. BERTHOU

\section{PROFESSEURS ÉMÉRITES}

$\begin{array}{ll}\text { CENAC Arnaud } & \text { Médecine interne } \\ \text { LEHN Pierre } & \text { Biologie Cellulaire } \\ \text { YOUINOU Pierre } & \text { Immunologie }\end{array}$

PROFESSEURS DES UNIVERSITÉS EN SURNOMBRE

\begin{tabular}{ll}
\hline COLLET Michel & Gynécologie - Obstétrique \\
MOTTIER Dominique & Thérapeutique \\
RICHE Christian & Pharmacologie fondamentale \\
SENECAIL Bernard & Anatomie \\
PROFESSEURS DES UNIVERSITÉS - PRATICIENS HOSPITALIERS DE CLASSE EXCEPTIONNELLE \\
\hline BOLES Jean-Michel & Réanimation Médicale \\
COCHENER - LAMARD Béatrice & Ophtalmologie \\
DEWITTE Jean-Dominique & Médecine \& Santé au Travail \\
FEREC Claude & Génétique \\
JOUQUAN Jean & Médecine Interne \\
LEFEVRE Christian & Anatomie \\
OZIER Yves & Anesthésiologie et Réanimation Chirurgicale \\
ROBASZKIEWICZ Michel & Gastroentérologie - Hépatologie \\
\hline \hline
\end{tabular}




\section{UB०}

PRofesseurs des UNIVERSités - Praticiens hospitaliers de 1ére CLASSE

BAIL Jean-Pierre

BERTHOU Christian

BLONDEL Marc

BRESSOLLETTE LUC

DE PARSCAU DU PLESSIX LOÏC

DE BRAEKELEER MarC

DELARUE Jacques

DUBRANA Frédéric

FENOLL Bertrand

FOURNIER Georges

GILARD Martine

GOUNY Pierre

HU Weiguo

KERLAN Véronique

LACUT Karine

LEROYER Christophe

LE MEUR Yannick

LE NEN Dominique

LOZAC'H Patrick

MANSOURATI Jacques

MARIANOWSKI Rémi

MISERY Laurent

NONENT Michel

PAYAN Christopher

REMY-NERIS Olivier

SALAUN Pierre-Yves

SARAUX Alain

SIZUN Jacques

TILLY - GENTRIC Armelle

TIMSIT Serge

VALERI Antoine

WALTER Michel
Chirurgie Digestive

Hématologie - Transfusion

Biologie cellulaire

Médecine Vasculaire

Pédiatrie

Génétique

Nutrition

Chirurgie Orthopédique et Traumatologique

Chirurgie Infantile

Urologie

Cardiologie

Chirurgie Vasculaire

Chirurgie plastique, reconstructrice \& esthétique ; brûlologie

Endocrinologie, Diabète \& maladies

métaboliques

Thérapeutique

Pneumologie

Néphrologie

Chirurgie Orthopédique et Traumatologique

Chirurgie Digestive

Cardiologie

Oto. Rhino. Laryngologie

Dermatologie - Vénérologie

Radiologie \& Imagerie médicale

Bactériologie - Virologie; Hygiène

Médecine Physique et Réadaptation

Biophysique et Médecine Nucléaire

Rhumatologie

Pédiatrie

Gériatrie \& biologie du vieillissement

Neurologie

Urologie

Psychiatrie d'Adultes 


\section{UB०}

Professeurs des UniVERSitÉs - Praticiens Hospitaliers de 2 ème CLASSE

ANSART Séverine
AUBRON Cécile
BEN SALEM Douraied
BERNARD-MARCORELLES Pascale
BEZON Eric
BOTBOL Michel
CARRE Jean-Luc
COUTURAUD Francis
DAM HIEU Phong
DEVAUCHELLE-PENSEC Valérie
GIROUX-METGES Marie-Agnès
HUET Olivier
LIPPERT Éric
LE GAL Grégoire
LE MARECHAL Cédric
L'HER Erwan
MONTIER Tristan
NEVEZ Gilles
NOUSBAUM Jean-Baptiste
PRADIER Olivier
RENAUDINEAU Yves
SEIZEUR Romuald
STINDEL Éric

Maladies infectieuses, maladies tropicales

Réanimation ; médecine d'urgence

Radiologie \& Imagerie médicale

Anatomie et cytologie pathologiques

Chirurgie thoracique et cardiovasculaire

Psychiatrie Infantile

Biochimie et Biologie moléculaire

Pneumologie

Neurochirurgie

Rhumatologie

Physiologie

Anesthésiologie - Réanimation Chirurgicale/Médecine d'urgences

Hématologie ; transfusion : option hématologie

Médecine interne

Génétique

Réanimation Médicale

Biologie Cellulaire

Parasitologie et Mycologie

Gastroentérologie - Hépatologie

Cancérologie - Radiothérapie

Immunologie

Anatomie-Neurochirurgie

Biostatistiques, Informatique Médicale \& technologies de communication

PRofesseur des UNIVERSITÉs - PRATICIEN LibéRAL

LE RESTE Jean Yves Médecine Générale

\section{PROFESSEUR DES UNIVERSITÉS ASSOCIÉS À MI-TEMPS}

$\begin{array}{ll}\text { BARRAINE Pierre } & \text { Médecine Générale } \\ \text { LE FLOC'H Bernard } & \text { Médecine Générale }\end{array}$




\title{
UBß
}

PROFESSEUR DES UNIVERSITÉS - LRU

\author{
BORDRON Anne Biochimie et Biologie moléculaire
}

MAITTRES de CONFÉRENCES dES UNIVERSITÉS - PRATICIENS HOSPITALIERS DE HORS CLASSE
LE MEVEL Jean Claude
Physiologie

MAîTRES de CONFÉRENCES des UNIVERSitéS - PRATICIENS HoSPITALIERS DE 1ÈRE CLASSE

$\begin{array}{ll}\text { ABGRAL Ronan } & \text { Biophysique et Médecine nucléaire } \\ \text { DELLUC Aurélien } & \text { Médecine interne } \\ \text { DE VRIES Philine } & \text { Chirurgie infantile } \\ \text { DOUET-GUILBERT Nathalie } & \text { Génétique } \\ \text { HERY-ARNAUD Geneviève } & \text { Bactériologie - Virologie; Hygiène } \\ \text { HILLION Sophie } & \text { Immunologie } \\ \text { JAMIN Christophe } & \text { Immunologie } \\ \text { LE BERRE Rozenn } & \text { Maladies infectieuses-Maladies tropicales } \\ \text { LE GAC Gérald } & \text { Génétique } \\ \text { LE ROUX Pierre-Yves } & \text { Biophysique et Médecine nucléaire } \\ \text { LODDE Brice } & \text { Médecine et santé au travail } \\ \text { MIALON Philippe } & \text { Physiologie } \\ \text { MOREL Frédéric } & \text { Médecine \& biologie du développement } \\ \text { PERSON Hervé } & \text { \& de la reproduction } \\ \text { PLEE-GAUTIER Emmanuelle } & \text { Anatomie } \\ \text { QUERELLOU Solène } & \text { Biochimie et Biologie Moléculaire } \\ \text { VALLET Sophie } & \text { Biophysique et Médecine nucléaire } \\ \end{array}$

MAÎTRES de CONFÉRENCES dES UNIVERSITÉS - PRATICIENS HOSPITALIERS DE 2ÈME CLASSE

$\begin{array}{ll}\text { BROCHARD Sylvain } & \text { Médecine Physique et Réadaptation } \\ \text { CORNEC Divi } & \text { Rhumatologie } \\ \text { LE GAL Solène } & \text { Parasitologie et Mycologie } \\ \text { PERRIN Aurore } & \begin{array}{l}\text { Biologie et médecine du développement \& } \\ \text { de la reproduction }\end{array} \\ \text { TALAGAS Matthieu } & \text { Cytologie et histologie }\end{array}$

MAÎTRES DE CONFÉRENCES DES UNIVERSITÉS - PRATICIENS HOSPITALIERS STAGIAIRES
LE VEN Florent
Cardiologie 


\section{UB⿵}

MAITRE DE CONFÉRENCES - CHAIRE INSERM

MIGNEN Olivier Physiologie

MAîTRES DE CONFÉRENCES ASSOCIÉS DES UNIVERSITÉ MI-TEMPS

$\begin{array}{ll}\text { BARAIS Marie } & \text { Médecine Générale } \\ \text { CHIRON Benoît } & \text { Médecine Générale } \\ \text { NABBE Patrice } & \text { Médecine Générale }\end{array}$

MAÎTRES DE CONFÉRENCES DES UNIVERSITÉS

$\begin{array}{ll}\text { BERNARD Delphine } & \text { Biochimie et biologie moléculaire } \\ \text { FAYAD Hadi } & \begin{array}{l}\text { Génie informatique, automatique et traitement } \\ \text { du signal }\end{array} \\ \text { HAXAIRE Claudie } & \text { Sociologie - Démographie } \\ \text { KARCHER Brigitte } & \text { Psychologie clinique } \\ \text { LANCIEN Frédéric } & \text { Physiologie } \\ \text { LE CORRE Rozenn } & \text { Biologie cellulaire } \\ \text { MORIN Vincent } & \text { Électronique et Informatique }\end{array}$

MAîTRES DE CONFÉRENCES ASSOCIÉS DES UNIVERSITÉS A TEMPS COMPLET

MERCADIE Lolita Rhumatologie

AGRÉGÉs / CERTIFIÉS DU SECOND DEGRÉ

$\begin{array}{ll}\text { MONOT Alain } & \text { Français } \\ \text { RIOU Morgan } & \text { Anglais }\end{array}$




\section{REMERCIEMENTS}

A Douraied, je te remercie d'avoir dirigé ma thèse et de la présider. Merci pour ton enseignement précieux, ta disponibilité et tes nombreuses anecdotes toujours intéressantes. Et enfin merci pour le togolais en ville!

A Luc, je te remercie pour ce semestre passé en Doppler où j'ai beaucoup appris et passé de très bons moments. Merci encore de m'avoir proposé de faire un tour dans ta kangoo tôlée quand ma voiture était au garage.

A Jean, je te remercie pour ton enseignement toujours claire et précis, tes conseils avisés ainsi que tes contacts avec la gendarmerie de Châteaulin qui ont permis d'initier mon travail de mémoire de DES.

A Claire, je te remercie pour ton implication et ton enthousiasme qui ont permis à la radiologie et la médecine légale de travailler ensemble sur différents projets. Merci pour tes nombreux contacts qui nous ont aidé dans plusieurs travaux de thèse et de mémoire.

A Mathieu, je te remercie pour avoir partagé avec moi tes connaissances radiologiques et surtout pour m'avoir fait découvrir la richesse du surf en Bretagne. On en aura fait des kilomètres pour parfois surfer des vagues pourries!

A ma femme Anna, je te remercie pour ton soutien depuis toutes ces années, ta patience malgré mon sale caractère et tes petites attentions au quotidien. A mon fils Issa, futur surfeur professionnel, et à mon chien Balrog.

A mes parents, pour m'avoir supporté jusqu'à 25 ans à la maison. A mon frère et ma sœur, qui j'espère, donneront bientôt des cousins et cousines à Issa.

A mes grands-parents et aux grands-parents d'Anna avec qui j'ai passé de beaux étés et des repas mémorables.

A tous les internes de la radiologie Brestoise, les vieux comme les jeunes, avec qui j’ai passé de bons moments en stage, au bar et dans l'eau. A Romain, pour sa si belle poitrine de l'été 2011 à la Réunion. A Ali, le predator nous manque. A Fabien, pour ses prouesses de pole dance. A Antoine, pour les batailles de nerf. A Pierre, l'homme le plus drôle du monde. Au professeur Ognart, pour son enseignement. A Anais, Lucile et Marine qui apportent une touche de classe et de féminité. A Morgan, pour m'avoir abandonné seul en vacation afin d'aller en soirée. A Divad, pour ses bonnes soirées et ses bonnes bouffes. A Adèle, pour tes 
délicieux gâteaux et pour tous les marmots que tu te coltines à notre place. A Brendan, pour tes bonnes blagues et tous les Dopplers que tu te coltines à notre place. Au bon Dr Bouttier, qui sait se servir des coquillages. A Jawad, pour son sens du style. A Jean-Patrick, bg du 29, pour la déconnade perpétuelle. A Florent, pour ce super semestre en os et pour sa bogossitude. A Valentin, le meilleur d'entre nous. A Thomas, aka Tony Stark qui roule en Volvo. A Fanfi et Michel, avec qui j'ai passé un super été à Quimper. A Fred, pour ses bons petits plats et ses goûts musicaux. A René, qui m'a fait aimer la radiologie lors de mon premier stage à Landerneau et qui a toujours des histoires passionnantes à raconter. A Raymond, pour sa bonne humeur constante et sa disponibilité. A Isabelle, pour m'avoir fait découvrir les seins. A Sandra, sans qui j'aurais souvent loupé l'heure du déjeuner. A toutes les équipes de la Cavale, de Morvan, de l'HIA, de Landerneau, de Lannion et de Quimper.

A Fred, Sophie et Adrien, pour les bons moments passés autour d'un barbecue ou dans l'eau. A David, Adri, Clément et Alexandre, pour ces années d'externat mémorables. A tous les nazes du BSP. A tous ceux que j'ai pu oublier, merci encore ! 
Is dual-energy computed tomography helpful to determinate the ferromagnetic property of bullets?

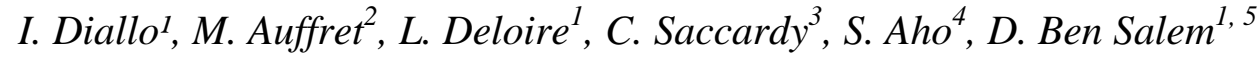

${ }^{1}$ Forensic Imaging Unit, University Hospital of Brest. Bd Tanguy Prigent, 29609 Brest Cedex, France.

${ }^{2}$ Imaging and Radiology Service, Brittany Atlantic Hospital of Vannes. 20 Bd Général Maurice Guillaudot, 56000 Vannes, France.

${ }^{3}$ Clinical Forensic Medicine and Pathology, University Hospital of Brest. Bd Tanguy Prigent, 29609 Brest Cedex, France.

${ }^{4}$ Department of Hospital Hygiene and Epidemiology, University Hospital of Dijon. 14 rue Paul Gaffarel, 21079 Dijon, France.

${ }^{5}$ LaTIM, INSERM UMR 1101. European University of Brittany, 2 avenue Foch, 29609 Brest cedex, France. 


\begin{abstract}
:
Objectives: The goal of this ex vivo study was to determine if Dual-Energy Computed Tomography (DECT) can discriminate ferromagnetic bullets from non-ferromagnetic bullets.

Methods: Twelve different bullets, placed in the center of the scanner on a gelatin phantom, underwent DECT evaluation. These projectiles were both ancient bullets from the 19Th century (eg. $8 \mathrm{~mm} 1890 \mathrm{ECP}$ ) and recent bullets from the late 20th century (eg. 9mm Lüger; $7.92 \mathrm{~mm}$ Mauser; $7 \mathrm{~mm}$ sport carabin). Two independent radiologists who were blinded to the properties of bullets performed all measurement on an external workstation with extended CT scale. Regions of interest (ROI) were placed in the core of each projectile. From these data, a dual-energy index (DEI) was calculated. A bootstrap method with a p value of less than 0.05 was used to demote statistical significance.
\end{abstract}

Results: Five bullets were ferromagnetic and seven were non-ferromagnetic. The DEI calculated were significantly $(p<0.05)$ different between the ferromagnetic and nonferromagnetic projectiles. There were no significant difference $(p>0.05)$ for intrareader and interreader agreement analysis.

Conclusion: Dual-energy CT, despite several limitations, could be a valid method to differentiate ferromagnetic from non-ferromagnetic bullets in an ex-vivo environment with extended CT-scale. This approach could contribute to MR safety but further studies are necessary before using dual-energy $\mathrm{CT}$ as a routine technique for screening gunshots victims.

Keywords: Dual-energy Computed Tomography; Forensic imaging; MRI safety; Bullets injury 


\section{Is dual-energy computed tomography helpful to determinate the ferromagnetic property of bullets?}

\section{Introduction:}

Gunshot injuries, resulting in retained bullets, are frequent (1). Because magnetic resonance imaging (MRI) can be used as a part of the damage evaluation process, it is crucial to determinate the ferromagnetic property of a retained object before any MRI procedure (210). Bullets are often made of non-ferromagnetic materials and will not cause patient injuries due to movement or dislodgment in tissue (10). But there are a significant number of ferromagnetic bullets $(2,11-13)$. These ferromagnetic bullets can exhibit movement which can be regarded as dangerous for the surrounding tissue.

Conventional radiography, easily accessible, is useful to detect metallic foreign bodies but is unsuitable to discriminate ferromagnetic material (such as iron or nickel) from nonferromagnetic material (such as lead). Dual-energy CT already proved its effectiveness for characterization of urinary calculi, measurement of contrast agent uptake or differentiation between cerebral hemorrhage and contrast (14-19). Dual-energy can discriminate elements with different atomic number (20) and therefore could be useful to distinguish ferromagnetic from non-ferromagnetic ballistic projectiles. Bullets are often made of steel (iron), lead, copper, brass (a copper-zinc alloy) and melchior (a copper-nickel-zinc alloy) (11-13). These different elements have significant difference between their atomic number: iron is 26 , lead is 82 , copper is 29 , zinc is 30 and nickel is 28 .

The goal of this ex vivo study was to determine if DECT can discriminate ferromagnetic bullets from non-ferromagnetic bullets.

\section{Materials and Methods:}

\section{Bullets}

Twelve different bullets (Table 1) underwent DECT evaluation in this study. These projectiles were both ancient bullets from the $19^{\mathrm{Th}}$ century and recent bullets from the late $20^{\text {th }}$ century. The exact compositions of these bullets were unknown. The ferromagnetic properties of the bullets have been tested using the deflection angle and torque methods (21) used in numerous studies $(5,10,22-26)$. The sample was attached to a stable non-

ferromagnetic test fixture using a string ( 20 -cm length; weight $<1 \%$ of each bullet) which was attached to the $0^{\circ}$ indicator of a plastic protractor. The apparatus was then placed eccentrically near the MR scanner portal. The deflection angle from the vertical position to the nearest degree was measured three times and the mean value was calculated (Table 1). Torque was assessed using a qualitative measurement technique. The bullet was attached to a string at the center of a PVC sheet. Each test samples were oriented $45^{\circ}$ to the static magnetic field and introduced into the center of the bore where magnetic torque is the greatest. The following qualitative scale was applied: 0 , no torque; +1 , low torque (object shifted slightly but did not align to the magnetic field); +2 , moderate torque (object aligned gradually to the magnetic field); +3 , strong torque (object aligned rapidly and forcefully to the magnetic field); and +4 , very strong torque (object very rapidly and very forcefully aligned to the magnetic field). 
Table 1

Description of ballistic tested

$\begin{array}{llll}\text { Item no. Details } & \begin{array}{l}\text { Ferromagnetic } \\ \text { property }\end{array} & \begin{array}{l}\text { Deflection } \\ \text { angle }\end{array}\end{array} \quad \begin{aligned} & \text { Torque } \\ & \end{aligned}$

\begin{tabular}{|c|c|c|c|c|}
\hline 1 & $\begin{array}{l}\text { 7.92mm Mauser } \\
\text { (world war 2) }\end{array}$ & + & 90 & $4+$ \\
\hline 2 & $\begin{array}{l}\text { 8mm Lebel training } \\
\text { (world war 1) }\end{array}$ & - & 0 & 0 \\
\hline 3 & $8 m m 1890$ ECP & - & 0 & 0 \\
\hline 4 & $9 m m$ & - & 0 & 0 \\
\hline 5 & $7.65 \mathrm{~mm}$ & - & 0 & 0 \\
\hline 6 & .44 Winchester & - & 0 & 0 \\
\hline 7 & 7.5mm Mas 36 & + & 90 & $4+$ \\
\hline 8 & $\begin{array}{l}.45 \mathrm{ACP} \text { or } \\
11.43 \mathrm{~mm}\end{array}$ & + & 90 & $4+$ \\
\hline 9 & $\begin{array}{l}9 m m \text { Lüger (world } \\
\text { war 2) }\end{array}$ & + & 90 & $4+$ \\
\hline 10 & $\begin{array}{l}7.62 \mathrm{~mm} \mathrm{MI} \\
\text { carabin (world war } \\
\text { 2) }\end{array}$ & - & 0 & 0 \\
\hline 11 & $7 \mathrm{~mm}$ sport carabin & + & 90 & $4+$ \\
\hline 12 & 6mm Bosquet & - & 0 & 0 \\
\hline
\end{tabular}

Methods of measurement

Each bullet was placed in the center of the scanner on a gelatin phantom. Data acquisition was performed on 128-section CT scanner (SOMATOM AS +; Siemens healthcare, Munich, Germany). Each projectile undergone two acquisition at $100 \mathrm{kV}$ and 140 $\mathrm{kV}$ using the following scanning parameters (11): slice collimation $(2 \times 64 \times 0,6 \mathrm{~mm})$, slice acquisition $(2 \times 128 \times 0,6 \mathrm{~mm})$, rotation time (0,5 seconds), pitch $(0,6)$, CT dose index $(9,8$ mGy). Data reconstructions was carried out using a sharp tissue kernel (b70), a slice thickness of $1,5 \mathrm{~mm}$, a slice increment of $1,0 \mathrm{~mm}$ and an extended Hounsfield Unit (HU) CT scale $(27,28)$.

\section{Outcome}

Two independent radiologists (R1, a junior radiologist, with 3 years of experience; $\mathrm{R} 2$, a senior radiologist, with 7 years of experience) who were blinded to the properties of bullets performed all measurement on an external workstation (Philipps IntelliSpace Portal, Amsterdam, Nederlands). Each CT number measurement was performed two times by each reader on independent axial CT images at all two tube voltage. Regions of interest (ROIs) 
were placed in the core of each projectile. For each bullet, placement of ROI had to be the widest possible without touching the jacket (Figure 1).

Figure 1

Example of ROI placement in bullet $n^{\circ} 4$

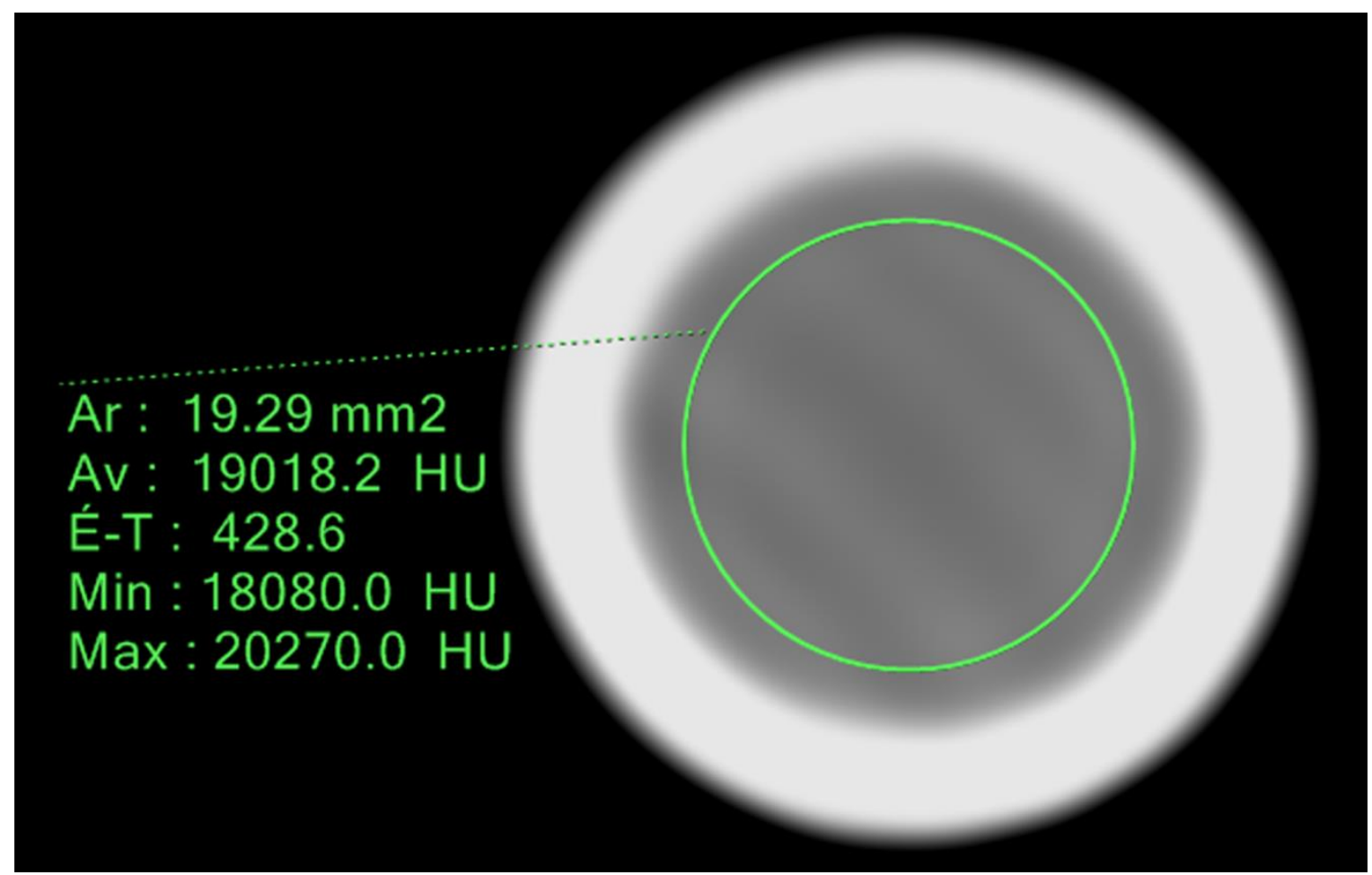

From these data, a dual-energy index (DEI) was calculated according to the following formula $(14,20)$ :

$$
D E I=\frac{\text { low } k V-h i g h k V}{\text { low } k V+h i g h k V+2000} H U
$$

To identify intrareader and interreader variability, measurements were repeated after an interval of one month to avoid recall bias.

Analysis

Statistical analysis was performed using StataCorp LP data analysis (StataCorp, 4905 Lakeway Drive; College Station, Texas 77845 USA). A bootstrap method with a $p$ value of less than 0.05 was used to demote statistical significance.

\section{Results:}

\section{Dual-energy analysis}

DEI were significantly ( $p<0.05$; 95\% CI: $-0.0110349,-0.0000267)$ lower in the core of ferromagnetic projectiles than those of non-ferromagnetic ones. Concerning ferromagnetic projectiles mean DEI was -0.04 ( $\mathrm{SD}=0.005$; range, -0.04 to -0.03 ). Regarding non-

ferromagnetic bullets mean DEI was -0.03 ( $\mathrm{SD}=0.006$; range, -0.04 to -0.02 ) (Table 2 and Figure 2). 
Table 2

DECT number of projectiles

$\begin{array}{lllll}\text { Mean DEI } & \text { Mean UH } & \text { Min UH } & \text { Max UH } & \text { ROI Surface } \\ \text { (SD) } & 100 / 140 \mathrm{kV} & 100 / 140 \mathrm{kV} & 100 / 140 \mathrm{kV} & 100 / 140 \mathrm{kV} \\ & & & & \left(\mathrm{mm}^{2}\right)\end{array}$

\begin{tabular}{llllll}
\hline $\begin{array}{l}\text { Ferromagnetic } \\
\text { bullets }\end{array}$ & $-0.037(0.005)$ & $17942 / 19427$ & $16880 / 18119$ & $19356 / 21146$ & $18.6 / 17,3$ \\
& $-0.031(0.006)$ & $18206 / 19430$ & $17101 / 18353$ & $20237 / 21637$ & $18,9 / 18,8$ \\
$\begin{array}{l}\text { Non- } \\
\text { ferromagnetic } \\
\text { bullets }\end{array}$ & & & & & \\
\hline
\end{tabular}

Figure 2

Box plot demonstrating the DEI of ferromagnetic and non-ferromagnetic bullets $(p<0.05)$

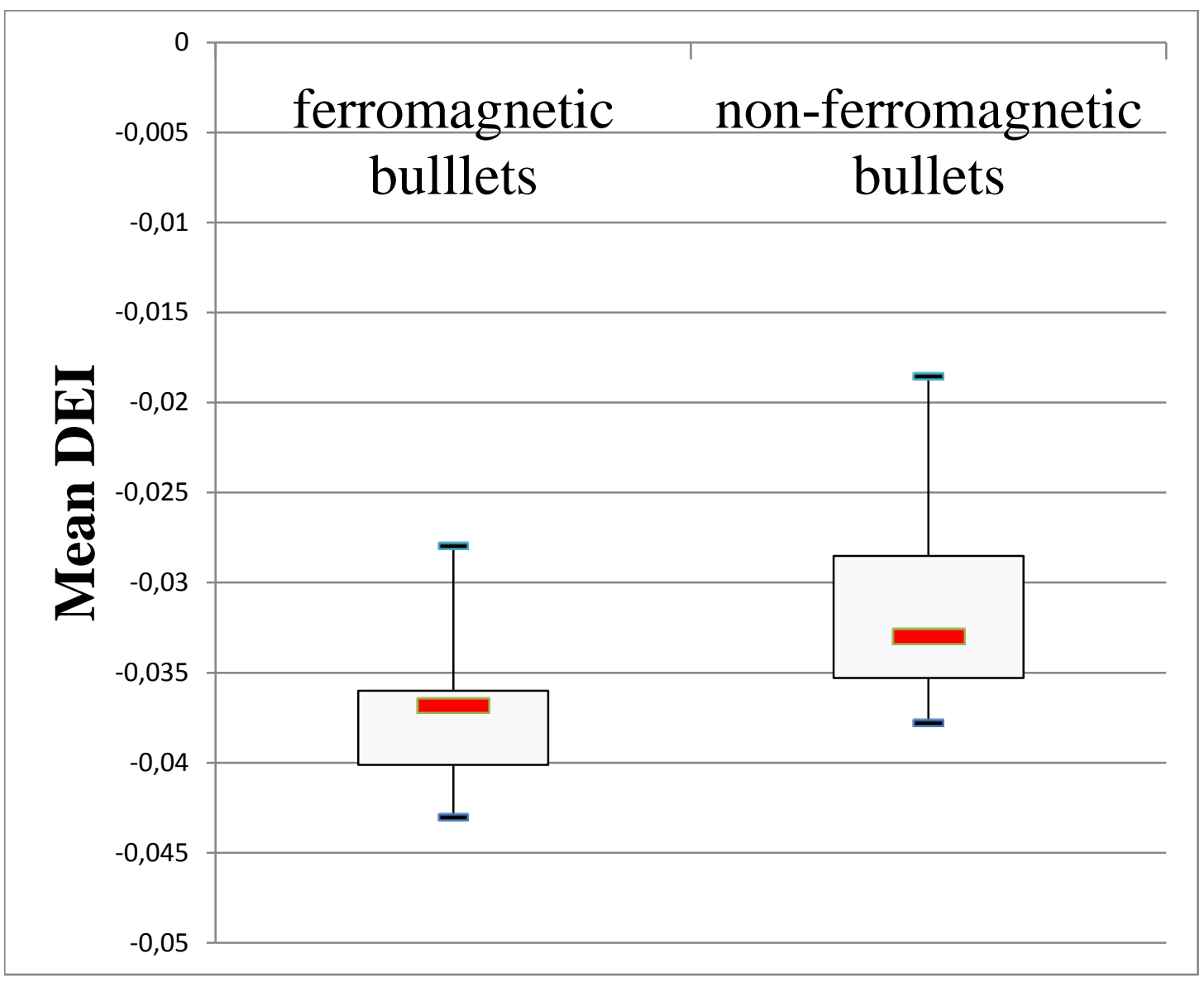




\section{Intrareader and interreader variability}

For intrareader agreement analysis, there were no significant differences ( $p=0.751$; 95\% CI: $-0.0005563,0.0007711$ ) (Figure 3). For interreader agreement analysis, there were no significant differences ( $p=0.785 ; 95 \%$ CI: $-0.0007593,0.0010052$ ) (Figure 4 ).

Figure 3

Box plots demonstrating mean DEI of ferromagnetic and non-ferromagnetic bullets intrareader agreement analysis $(p=0.751)$

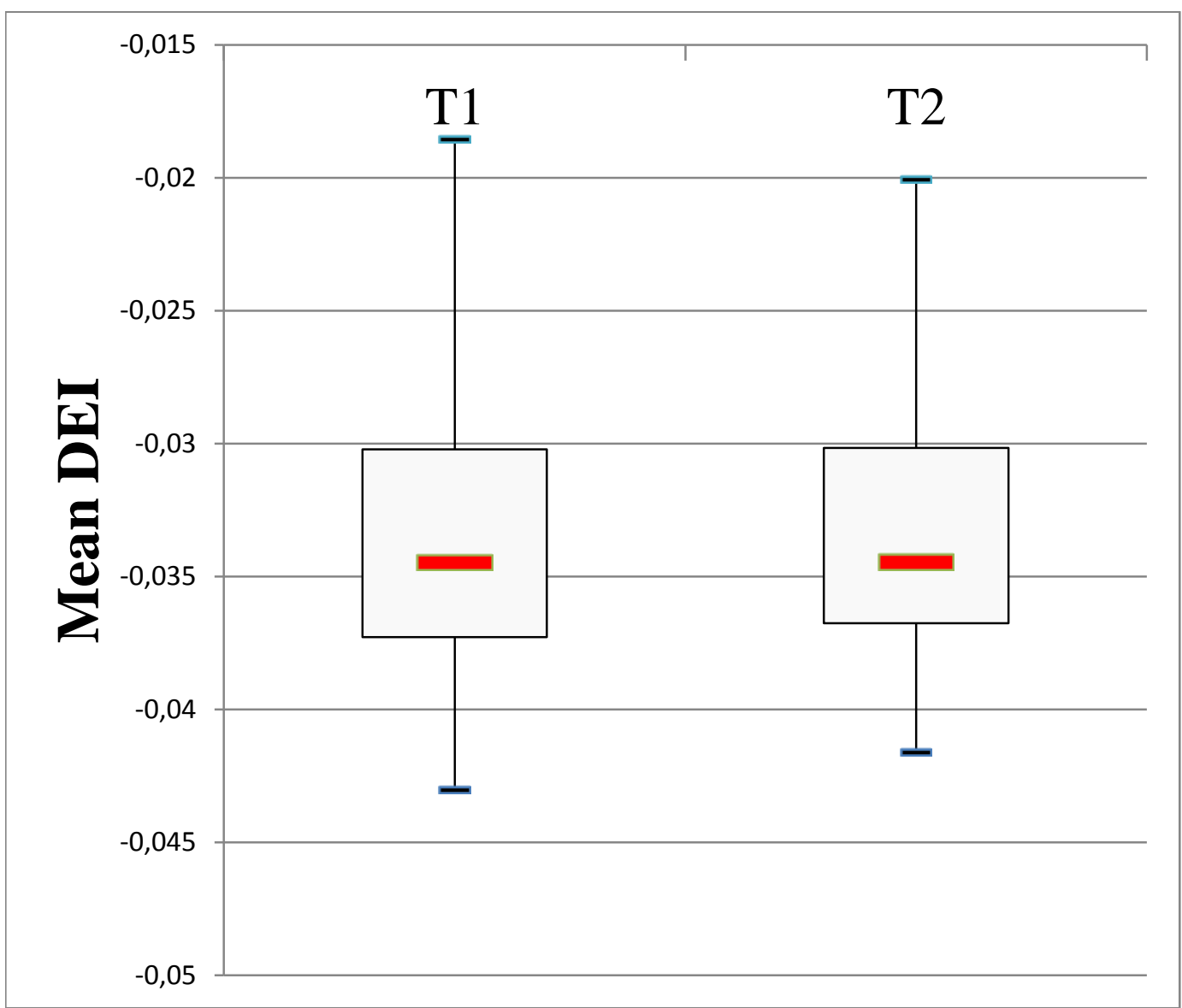

T1, first measurements ; T2, second measurements 
Figure 4

Box plots demonstrating mean DEI of ferromagnetic and non-ferromagnetic bullets interreader agreement analysis $(p=0.785)$

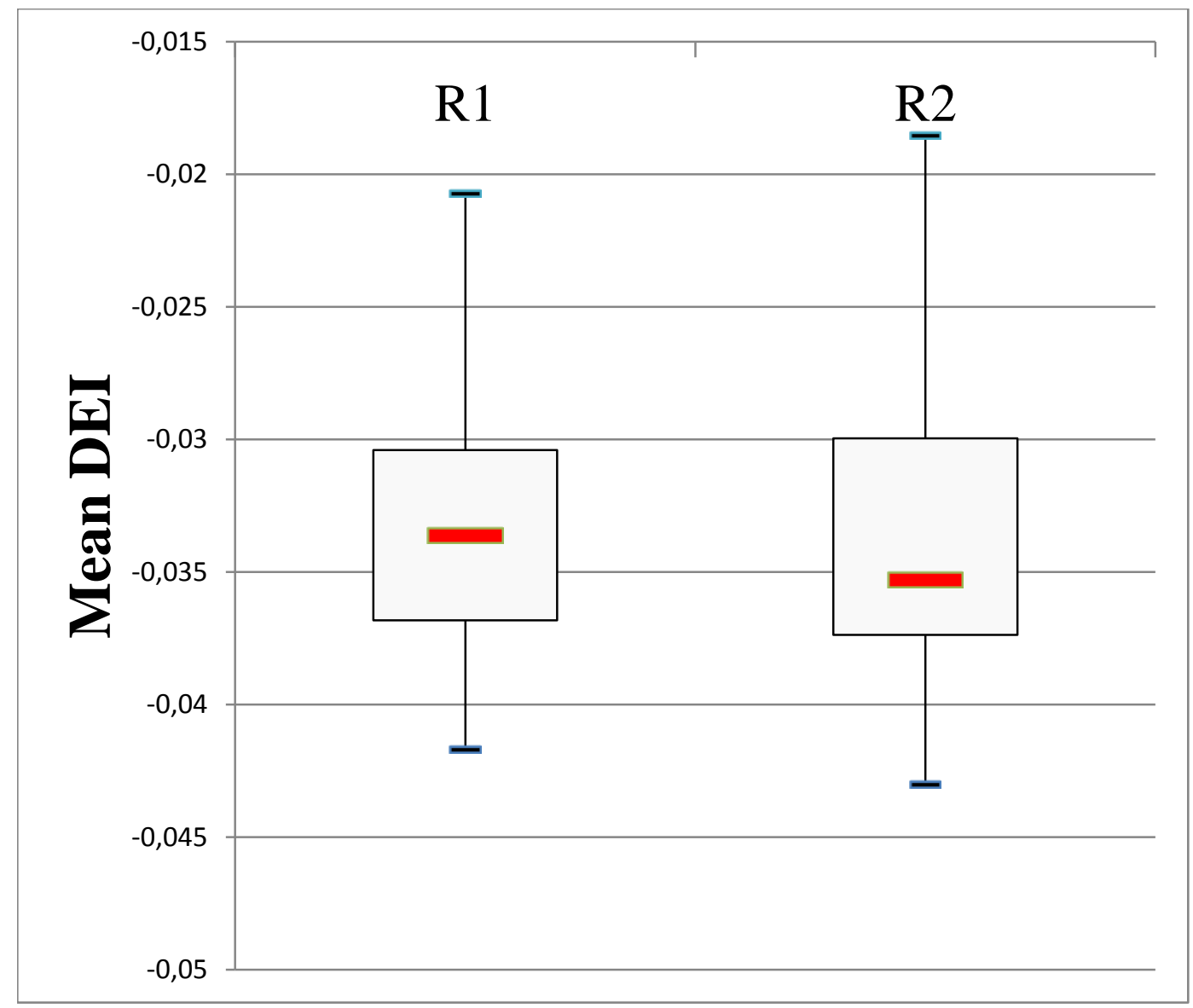

$\mathrm{R} 1$, radiologist $\mathrm{n}^{\circ} 1 ; \mathrm{R} 2$, radiologist $\mathrm{n}^{\circ} 2$

\section{Discussion:}

Our study demonstrates that DECT can distinguish ferromagnetic from nonferromagnetic bullets at extended CT scale. These findings are consistent with the theoretical principle of DEI and the results from precious studies $(11,14,15,20)$. Indeed, DECT acquires data using two different energy levels, it is capable of differentiating materials with different atomic numbers despite similar attenuation coefficients. As described in the literature, ROI measurements to quantify the x-ray attenuation is a reliable and a reproducible method (29). Any radiologist without specific training required can place a spherical ROI in a bullet. Only a fraction of patient who need a MRI procedure present a metallic foreign projectile in their body. Nowadays, these patients are usually disqualified from MRI. However, a large number of bullets are not ferromagnetic.

There are several limitations to our study. This ex-vivo analysis cannot yet be transposed to the living and the routine emergency radiology. The ballistics tested are undamaged projectiles analyzed in a controlled environment. Though, when a bullet enters a body, it will deform and sometimes break into small pieces. The influence of size and shape of the projectile have not been taken into account in our analysis. The same applies to the location of the foreign object in the patient's body (4). A deeply buried bullet could be more 
difficult to analyze than a superficial projectile. Indeed artifacts such as beam hardening if the bullet is stuck into a hard tissue could contaminate the attenuation measurements (29). Also, we did not place a ROI on the bullet's jacket. Winklhofer and al. have shown that measurements on the jacket are unhelpful (11). In addition, some of our bullets are from the early $20^{\text {th }}$ century but ancient weapons are still in use nowadays (30,31). In our study, a bullet with a lower DEI is more likely to be ferromagnetic. But despite a significant difference between ferromagnetic and non-ferromagnetic bullets, there is no cut-off DEI value to differentiate these two groups. A bullet with low DEI is more likely to be ferromagnetic but DEI values are overlapping (Figure 2). These data are in contradiction with the previous study of Winklhofer and al. (11) despite using the same scanning parameters. However, as mentioned in Winklhofer's study, the composition of a X-ray beam varies between CT manufacturers, between scanners, and on the age of the x-ray tube. The Hounsfield unit values are not necessarily reproducible on a different scanner. That is why each scanner should be calibrated with a pure sample of each metal. Furthermore, previous studies demonstrated that the CT values of high-density absorbers will vary significantly if scanned with different CT scanners despite using the same scan parameters (29). Due to this limitation, DECT cannot yet be used for screening patients in a clinical routine. Hence, it seems necessary to carry forward studies on this subject before beginning to use this technique in order to screen living patients.

\section{Conclusion:}

DECT, despite several limitations, could be a valid method to differentiate ferromagnetic from non-ferromagnetic bullets in an ex-vivo environment with extended CTscale. This approach could contribute to MR safety but further studies are necessary before using dual-energy CT as a routine technique for screening gunshots victims. 


\section{References:}

1. Ranney ML, Sankoff J, Newman DH, Fenton A, Mukau L, Durston WE, et al. A call to action: firearms, public health, and emergency medicine. Ann Emerg Med. 2013;61:700702 .

2. Eshed I, Kushnir T, Shabshin N, Konen E. Is magnetic resonance imaging safe for patients with retained metal fragments from combat and terrorist attacks? Acta Radiol. 2010;51(2):170-4.

3. Woods TO. Standards for medical devices in MRI: present and future. J Magn Reson Imaging JMRI. 2007;26(5):1186-9.

4. Shellock FG. Reference Manual for Magnetic Resonance Safety, Implants, and Devices: 2014 Edition. Los Angeles, CA, Biomedical Research Publishing Group, 2014.

5. Kumar R, Lerski RA, Gandy S, Clift BA, Abboud RJ. Safety of orthopedic implants in magnetic resonance imaging: an experimental verification. J Orthop Res Off Publ Orthop Res Soc. 2006;24(9):1799-802.

6. Shellock FG. MR imaging of metallic implants and materials: a compilation of the literature. AJR Am J Roentgenol. 1988;151(4):811-4.

7. Shellock FG. MR imaging in patients with intraspinal bullets. J Magn Reson Imaging JMRI. 1999;10(1):107.

8. Jourdan P, Cosnard G. MRI: projectiles, bullets and counter-indications. J Radiol. 1989;70(12):685-9.

9. Dedini RD, Karacozoff AM, Shellock FG, Xu D, McClellan RT, Pekmezci M. MRI issues for ballistic objects: information obtained at 1.5-, 3- and 7-Tesla. Spine J.

2013;13(7):815-22.

10. Teitelbaum GP, Yee CA, Van Horn DD, Kim HS, Colletti PM. Metallic ballistic fragments: MR imaging safety and artifacts. Radiology. 1990;175(3):855-9.

11. Winklhofer S, Stolzmann P, Meier A, Schweitzer W, Morsbach F, Flach P, et al. Added Value of Dual-Energy Computed Tomography Versus Single-Energy Computed Tomography in Assessing Ferromagnetic Properties of Ballistic Projectiles: Implications for Magnetic Resonance Imaging of Gunshot Victims. Invest Radiol. 2014;49(6):431-437.

12. Karacozoff AM, Pekmezci M, Shellock FG. Armor-piercing bullet: 3-T MRI findings and identification by a ferromagnetic detection system. Mil Med. 2013;178(3):e380-385.

13. Walker JJ, Kelly JF, McCriskin BJ, Bader JO, Schoenfeld AJ. Combat-related gunshot wounds in the United States military: 2000-2009 (cohort study). Int J Surg Lond Engl.

2012;10(3):140-3. 
14. Graser A, Johnson TRC, Bader M, Staehler M, Haseke N, Nikolaou K, et al. Dual energy CT characterization of urinary calculi: initial in vitro and clinical experience. Invest Radiol. févr 2008;43(2):112-9.

15. Stolzmann P, Scheffel H, Rentsch K, Schertler T, Frauenfelder T, Leschka S, et al. Dual-energy computed tomography for the differentiation of uric acid stones: ex vivo performance evaluation. Urol Res. août 2008;36(3-4):133-8.

16. Gupta R, Phan CM, Leidecker C, Brady TJ, Hirsch JA, Nogueira RG, et al. Evaluation of Dual-Energy CT for Differentiating Intracerebral Hemorrhage from Iodinated Contrast Material Staining 1. Radiology. 2010;257(1):205-211.

17. Stolzmann P, Kozomara M, Chuck N, Müntener M, Leschka S, Scheffel H, et al. In vivo identification of uric acid stones with dual-energy $\mathrm{CT}$ : diagnostic performance evaluation in patients. Abdom Imaging. oct 2010;35(5):629-35.

18. Feuerlein S, Heye TJ, Bashir MR, Boll DT. Iodine quantification using dual-energy multidetector computed tomography imaging: phantom study assessing the impact of iterative reconstruction schemes and patient habitus on accuracy. Invest Radiol. nov 2012;47(11):65661.

19. Mansouri M, Aran S, Singh A, Kambadakone AR, Sahani DV, Lev MH, et al. DualEnergy Computed Tomography Characterization of Urinary Calculi: Basic Principles, Applications and Concerns. Curr Probl Diagn Radiol. nov 2015;44(6):496-500.

20. Krauss B, Schmidt B, Flohr TG. Dual source CT. In: Johnson TRC, Fink C, Schönberg SO, Reiser MF, eds. Dual Energy CT Dual energy CT in clinical Practice. Heidelberg, Germany: Springer, 2011:11-20.

21. American Society for Testing and Materials (ASTM). International: F2213. Standard Test Method for Measurement of Magnetically Induced Displacement Force on Medical Devices in the Magnetic Resonance Environment . In: Annual Book of ASTM Standards, Section 13, Medical Devices and Services, Volume 13.01, pp 1576-80. West Conshohocken, PA, ASTM International, 2001

22. Diallo I, Auffret M, Attar L, Bouvard E, Rousset J, Salem DB. Magnetic Field Interactions of Military and Law Enforcement Bullets at 1.5 and 3 Tesla. Mil Med. 2016. DOI: 10.7205/MILMED-D-15-00246.

23. Shellock FG. Metallic neurosurgical implants: evaluation of magnetic field interactions, heating, and artifacts at 1.5-Tesla. J Magn Reson Imaging JMRI. sept 2001;14(3):295-9.

24. Shellock FG, Gounis M, Wakhloo A. Detachable coil for cerebral aneurysms: in vitro evaluation of magnetic field interactions, heating, and artifacts at 3T. AJNR Am J Neuroradiol. févr 2005;26(2):363-6. 
25. Shellock FG, Valencerina S. In vitro evaluation of MR imaging issues at $3 \mathrm{~T}$ for aneurysm clips made from MP35N: Findings and information applied to 155 additional aneurysm clips. AJNR Am J Neuroradiol. 2010;31(4):615-9.

26. Weiland JD, Faraji B, Greenberg RJ, Humayun MS, Shellock FG. Assessment of MRI issues for the Argus II retinal prosthesis. Magn Reson Imaging. 2012;30(3):382-9.

27. Jackowski C, Lussi A, Classens M, Kilchoer T, Bolliger S, Aghayev E, et al. Extended CT scale overcomes restoration caused streak artifacts for dental identification in CT-3D color encoded automatic discrimination of dental restorations. J Comput Assist Tomogr. 2006;30(3):510-513.

28. Woisetschläger M, Lussi A, Persson A, Jackowski C. Fire victim identification by post-mortem dental CT: Radiologic evaluation of restorative materials after exposure to high temperatures. Eur J Radiol. 2011;80(2):432-40.

29. Ruder TD, Thali Y, Schindera ST, Torre SAD, Zech W-D, Thali MJ, et al. How reliable are Hounsfield-unit measurements in forensic radiology? Forensic Sci Int. 2012;220(1 $-3): 219-23$.

30. Four terror suspects found hiding in cave in southeast Turkey. In: Yeni Safak; March 2016. Retrieved on: http://www.yenisafak.com/en/news/four-terror-suspects-found-hiding-incave-in-southeast-turkey-2435571.

31. Alps murders: ex-policeman arrested in village near scene of al-Hilli shootings. In: The Guardian; February 2014. Retrieved on: http://www.theguardian.com/world/2014/feb/18/alps-murders-former-policeman-arrestedvillage-shootings 


\section{SERMENT D'HIPPOCRATE}

Au moment d'être admis à exercer la médecine, je promets et je jure d'être fidèle aux lois de l'honneur et de la probité.

Mon premier souci sera de rétablir, de préserver ou de promouvoir la santé dans tous ses éléments, physiques et mentaux, individuels et sociaux.

Je respecterai toutes les personnes, leur autonomie et leur volonté, sans aucune discrimination selon leur état ou leurs convictions. J'interviendrai pour les protéger si elles sont affaiblies, vulnérables ou menacées dans leur intégrité ou leur dignité. Même sous la contrainte, je ne ferai pas usage de mes connaissances contre les lois de l'humanité.

J'informerai les patients des décisions envisagées, de leurs raisons et de leurs conséquences. Je ne tromperai jamais leur confiance et n'exploiterai pas le pouvoir hérité des circonstances pour forcer les consciences.

Je donnerai mes soins à l'indigent et à quiconque me le demandera. Je ne me laisserai pas influencer par la soif du gain ou la recherche de la gloire.

Admis dans l'intimité des personnes, je tairai les secrets qui me seront confiés. Reçu à l'intérieur des maisons, je respecterai les secrets des foyers et ma conduite ne servira pas à corrompre les mœurs.

Je ferai tout pour soulager les souffrances. Je ne prolongerai pas abusivement les agonies. Je ne provoquerai jamais la mort délibérément.

Je préserverai l'indépendance nécessaire à l'accomplissement de ma mission. Je n'entreprendrai rien qui dépasse mes compétences. Je les entretiendrai et les perfectionnerai pour assurer au mieux les services qui me seront demandés.

J'apporterai mon aide à mes confrères ainsi qu'à leurs familles dans l'adversité.

Que les hommes et mes confrères m'accordent leur estime si je suis fidèle à mes promesses ; que je sois déshonoré et méprisé si j'y manque.

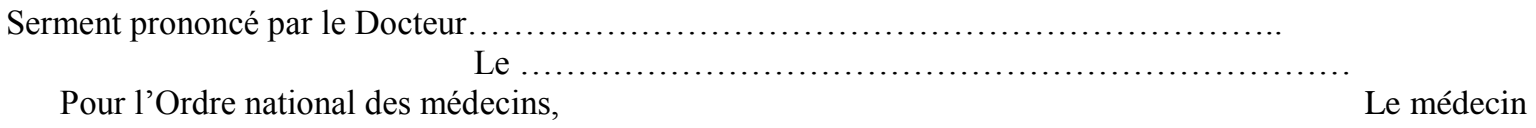


DIALLO (Idris) - Is dual-energy computed tomography helpful to determinate the ferromagnetic property of bullets? $22 \mathrm{f} ., 4$ ill., 2 tabl.

Th.: Méd.: Brest 2016

\section{RESUME :}

Objectives: The goal of this ex vivo study was to determine if Dual-Energy Computed

Tomography (DECT) can discriminate ferromagnetic bullets from non-ferromagnetic bullets.

Methods: Twelve different bullets, placed in the center of the scanner on a gelatin phantom, underwent DECT evaluation. These projectiles were both ancient bullets from the 19Th century (eg. $8 \mathrm{~mm} 1890 \mathrm{ECP}$ ) and recent bullets from the late 20th century (eg. 9mm Lüger; $7.92 \mathrm{~mm}$ Mauser; $7 \mathrm{~mm}$ sport carabin). Two independent radiologists who were blinded to the properties of bullets performed all measurement on an external workstation with extended CT scale. Regions of interest (ROI) were placed in the core of each projectile. From these data, a dual-energy index (DEI) was calculated. A bootstrap method with a $\mathrm{p}$ value of less than 0.05 was used to demote statistical significance.

Results: Five bullets were ferromagnetic and seven were non-ferromagnetic. The DEI calculated were significantly $(p<0.05)$ different between the ferromagnetic and non-ferromagnetic projectiles. There were no significant difference $(p>0.05)$ for intrareader and interreader agreement analysis.

Conclusion: Dual-energy CT, despite several limitations, could be a valid method to differentiate ferromagnetic from non-ferromagnetic bullets in an ex-vivo environment with extended CT-scale. This approach could contribute to MR safety but further studies are necessary before using dualenergy $\mathrm{CT}$ as a routine technique for screening gunshots victims.

\section{MOTS CLES :}

Dual-energy Computed Tomography; Forensic imaging; MRI safety; Bullets injury.

\section{JURY :}

Président:

M. le Professeur Douraied BEN SALEM

Membres:

M. le Professeur Luc BRESSOLLETTE

M. le Professeur Jean ROUSSET

Mme. le Docteur Claire SACCARDY

M. le Docteur Mathieu AUFFRET

\section{DATE DE SOUTENANCE :}

03 juin 2016

\section{ADRESSE DE L'AUTEUR :}

2 rue des Iles Marquises, 29000 Quimper 